\title{
Inherited Methylmalonyl CoA Mutase Apoenzyme Deficiency in Human Fibroblasts
}

\author{
EVIDENCE FOR ALLELIC HETEROGENEITY, GENETIC COMPOUNDS, \\ AND CODOMINANT EXPRESSION
}

\author{
Huntington F. Willard and LeON E. Rosenberg, Department of Human Genetics, \\ Yale University School of Medicine, New Haven, Connecticut 06510
}

\begin{abstract}
A B S T R A C T We have measured and characterized methylmalonyl coenzyme A (CoA) mutase activity in extracts of cultured human fibroblasts from 23 patients with inherited deficiency of the mutase apoenzyme and from eight obligate heterozygotes for this defect. The mutant cell lines fall into two categories. Those without detectable residual mutase activity in cell extracts $(>0.1 \%$ of control), and whose ability to utilize propionate in intact cells is refractory to supplementation of the culture medium with hydroxocobalamin, are designated $m u t^{\circ}$ mutants. Those with detectable residual activity in cell extracts $(\sim 0.5-50 \%$ of control), and whose ability to utilize propionate in intact cells is markedly increased by hydroxocobalamin supplementation, are designated mut ${ }^{-}$mutants. The mutant enzyme in the mut $^{-}$mutants exhibits a 50- to 5,000-fold elevated Michaelis constant $\left(K_{\mathrm{m}}\right)$ for adenosylcobalamin in vitro, a normal $K_{\mathrm{m}}$ for methylmalonyl CoA, and a strikingly reduced thermal stability at $45^{\circ} \mathrm{C}$ relative to control. Mutase from one $m u t^{-}$ mutant turns over at a rate three to four times that of control enzyme when cells are grown in hydroxocobalamin-supplemented medium.

To detect heterozygous carriers of mutant mut alleles, we compared mutase activity in fibroblast extracts from four controls with that from eight parents of either $m u t^{\circ}$ or $m u t^{-}$mutants. After cell growth in either unsupplemented or hydroxocobalamin-supplemented medium, activity in cell lines from heterozygotes was reduced to 47 or $37 \%$ of the mean control activities, respectively. We also examined the effect of adenosylcobalamin concentration on reaction kinetics of mutase from heterozygote cell lines. All four cell
\end{abstract}

Dr. Willard's present address is Division of Medical Genetics, The Johns Hopkins University School of Medicine, Baltimore, Md.

Received for publication 4 September 1979 and in revised form 19 November 1979. lines from parents of $\mathrm{mut}^{-}$mutants exhibited complex enzyme kinetics; $\sim 80 \%$ of mutase activity demonstrated a $K_{\mathrm{m}}$ indistinguishable from control, whereas a smaller component of activity exhibited a $K_{\mathrm{m}}$ similar to the abnormal $K_{\mathrm{m}}$ expressed by the $\mathrm{mut}^{-}$propositus in each family. In two families with a $m u t^{\circ}$ propositus, mutase from three of the four parents exhibited only the normal $K_{\mathrm{m}}$ for adenosylcobalamin, whereas mutase from one parent displayed complex kinetics, indicating expression of both a normal allele $\left(m u t^{+}\right)$and a mutant allele with an abnormal $K_{\mathrm{m}}$. From these studies, we conclude that mut mutants reflect mutations at the autosomal gene locus for the methylmalonyl CoA mutase apoenzyme; that $m u t^{\circ}, m u t^{-}$, and $m u t^{+}$alleles at this locus are codominantly expressed; and that some mut mutants may be genetic compounds, inheriting two different $m u t^{\circ}$ or $m u t^{-}$alleles from their parents.

\section{INTRODUCTION}

One of the five biochemically and genetically distinct mutant classes in the recessively inherited methylmalonic acidemias is characterized by an abnormal or absent methylmalonyl coenzyme $\mathrm{A}(\mathrm{CoA})$ mutase (EC 5.4.99.2) apoenzyme, the adenosylcobalamin (AdoCbl) ${ }^{1}$ dependent enzyme that catalyzes the rearrangement of L-methylmalonyl CoA to succinyl CoA (1). Cultured human fibroblasts belonging to this mutant class metabolize cobalamin (Cbl) normally (2-4), are severely deficient in mutase activity measured in crude extracts in vitro (3), and constitute a distinct genetic complementation group, designated mut $(5,6)$.

Previous studies with a limited number of cell lines belonging to this mutant class have established the existence of at least two distinct types of mut muta-

\footnotetext{
${ }^{1}$ Abbreviations used in this paper: AdoCbl, adenosylcobalamin; OH-Cbl, hydroxocobalamin; $\mathrm{V}_{\max }$, maximum velocity.
} 
tions. In one, mutase activity is undetectable in extracts of cultured fibroblasts, even when assayed in the presence of AdoCbl at concentrations greatly in excess of that normally required to saturate the enzyme $(3,7)$. In the second, mutase activity is detectable but exhibits a markedly reduced affinity for AdoCbl (7-9).

In the present report, we describe more extensive studies designed to elucidate the biochemical and genetic nature of the inherited defect in a large series of cell lines with a presumptive defect in the mutase apoenzyme.

\section{METHODS}

Cells and cell culture. Human skin fibroblasts were routinely maintained in $32 \mathrm{oz}$ glass bottles in Eagle's minimal essential medium supplemented with $10 \%$ fetal calf serum (Flow Laboratories, Inc., Rockville, Md.), $1 \%$ nonessential amino acids (Grand Island Biological Co., Grand Island, N. Y.), and $100 \mu \mathrm{g} / \mathrm{ml}$ kanamycin (Grand Island Biological Co.). For experiments, cells were plated at a $1: 4$ split ratio into $150-\mathrm{cm}^{2}$ tissue culture flasks and used $4 \mathrm{~d}$ later. Cells were grown either in basal medium containing $\sim 30 \mathrm{pg} \mathrm{Cbl} / \mathrm{ml}$ or in Cbl-supplemented medium, containing up to $1 \mu \mathrm{g} / \mathrm{ml}$ hydroxocobalamin (OH-Cbl) (10). OH-Cbl (Alpha Redisol) was obtained from Merck Sharpe and Dohme, Div. Merck \& Co., Inc., West Point, Pa.

Cell lines were derived from four normal individuals, from 23 patients with methylmalonic acidemia due to a defect in the mutase apoenzyme, and from eight obligate heterozygotes for mutase deficiency. Cell lines had been in culture for 3-21 passages at the time of study. Lines were periodically tested for mycoplasma contamination after growth in antibiotic-free medium; all tests performed either in our laboratory or at the Institute for Medical Research, Camden, N. J., were negative.

Assay of methylmalonyl CoA mutase activity. Methylmalonyl CoA mutase activity in cell-free extracts was determined radioisotopically by measuring the production of $\left[{ }^{14} \mathrm{C}\right]$ succinate from DL-[methyl $\left.-{ }^{14} \mathrm{C}\right]$ methylmalonyl CoA (45-55 mCi/mmol; New England Nuclear, Boston, Mass.), as described (7). Reactions were routinely initiated by addition of substrate and allowed to proceed for $7 \mathrm{~min}$ at $37^{\circ} \mathrm{C}$. All assays were performed in $0.2 \mathrm{M}$ Tris/sulfate, $\mathrm{pH} 7.4$ (7). Mutase activity is expressed as picomoles succinate formed per minute per milligram protein. The limit of detectability in these experiments was $2 \mathrm{pmol} / \mathrm{min}$ per mg. Protein content was determined by the method of Böhlen et al. (11). Methylmalonyl CoA mutase exists in cells either complexed with AdoCbl (mutase holoenzyme) or free of AdoCbl (mutase apoenzyme). "Endogenous holomutase activity" was measured by omitting AdoCbl from the reaction mixture. "Total mutase activity" (holoenzyme plus apoenzyme) was measured by including AdoCbl in the reaction mixture; for standard assays, the concentration used was $5.0-8.9 \mu \mathrm{M}$. The parameter "percent holoenzyme" was determined from the fraction of activity measured without added AdoCbl to that measured with added AdoCbl (12).

Assay of $\left[1-{ }^{14} \mathrm{C}\right]$ propionate utilization. Intact cells were assayed in situ as described (13) for their ability to incorporate ${ }^{14} \mathrm{C}$ from $\left[1-{ }^{14} \mathrm{C}\right]$ propionate into trichloroacetic acidprecipitable material as a measure of the total pathway activity from propionate to succinate. This assay measures collectively several enzymes, including methylmalonyl CoA mutase. Assays were performed 2-5 d after a 1:4 cell split.
Other procedures. Genetic complementation analyses (6), measurements of $\mathrm{Cbl}$ coenzyme synthesis in intact cells in culture $(6,14)$, thermostability studies $(12)$, and studies involving the protein inhibitor cycloheximide (15) were performed as described previously.

\section{RESULTS}

Classification of mut mutants. The 23 mutant cell lines employed in these studies were originally designated apoenzyme mutants by assays of mutase activity in crude extracts of cells grown in basal medium. When assayed in the presence of normally saturating concentrations of AdoCbl $(5.0-8.9 \mu \mathrm{M})$ $(7,16)$, mutase activity in these cell lines ranged from $<2$ to $50 \mathrm{pmol} / \mathrm{min}$ per $\mathrm{mg}$, or from $<0.1$ to $3 \%$ of mean control activity $(1,709 \pm 80 \mathrm{pmol} / \mathrm{min}$ per $\mathrm{mg}$; mean $\pm \mathrm{SEM}, n=4$ cell lines). Similarly, all 23 cell lines examined were severely deficient in the ability to incorporate ${ }^{14} \mathrm{C}$ from $\left[1-{ }^{14} \mathrm{C}\right]$ propionate into acidprecipitable material as a measure of endogenous mutase holoenzyme activity in intact cells. Mutant cells fixed 0.04-0.38 nanoatom ${ }^{14} \mathrm{C} / \mathrm{mg}$, compared with a mean control value of 8.20 nanoatom ${ }^{14} \mathrm{C} / \mathrm{mg}(10)$.

Each of the mutant lines was assigned to the mut complementation group by genetic complementation analysis (5-7). The prototype used by Gravel et al. (5) for this mutant class was cell line 77 . This cell line has undetectable mutase activity $(<2 \mathrm{pmol} / \mathrm{min}$ per $\mathrm{mg}$ ) measured both in the absence and in the presence of added $\mathrm{AdoCbl}$ and was obtained from the first patient demonstrated to exhibit a deficiency of the mutase apoenzyme (17). All attempts to demonstrate even partial complementation of the defect in propionate utilization in heterokaryons formed between any two mut mutants failed.

To rule out the possibility that some of the mut mutants also had defects in Cbl metabolism, we measured $\mathrm{Cbl}$ accumulation and $\mathrm{Cbl}$ coenzyme synthesis by intact cells in culture. The eight mut mutants examined in this way accumulated $\left.137-302 \mathrm{pg}{ }^{57} \mathrm{Co}\right]-$ $\mathrm{Cbl} / \mathrm{mg}$ protein from the medium and converted $3-12 \%$ of it to $\mathrm{Ado}\left[{ }^{57} \mathrm{Co}\right] \mathrm{Cbl}$ when grown $4-7 \mathrm{~d}$ in medium containing $50 \mathrm{pg} \mathrm{OH}-\left[{ }^{57} \mathrm{Co}\right] \mathrm{Cbl} / \mathrm{ml}$. Three control lines, under the same conditions, accumulated $187-361 \mathrm{pg}$ $\left[{ }^{57} \mathrm{Co}\right] \mathrm{Cbl} / \mathrm{mg}$ and converted $13-22 \%$ of it to $\mathrm{Ado}\left[{ }^{57} \mathrm{Co}\right]-$ Cbl. These data are similar to those from previous studies of AdoCbl synthesis in control and mut cell lines $(3,7)$. By comparison, cells with known inherited defects in AdoCbl synthesis converted $<1 \%$ of accumulated $\mathrm{Cbl}$ to $\mathrm{Ado}\left[{ }^{57} \mathrm{Co}\right] \mathrm{Cbl}$. Synthesis of the other Cbl coenzyme, methylcobalamin, was normal in the mut mutants examined. ${ }^{2}$

Propionate utilization by mut mutants in basal and

${ }^{2}$ Willard, H. F., and L. E. Rosenberg. Unpublished experiments. See ref. 18 . 
Cbl-supplemented medium. As an extension of our previous study to investigate the effect of $\mathrm{Cbl}$ supplementation in culture on mutase activity (10), mut cell lines were grown in medium supplementation with $\mathrm{OH}-\mathrm{Cbl}$ at concentrations up to $1 \mu \mathrm{g} / \mathrm{ml}$. As shown in Table I, two distinct patterns of response were observed, confirming previous results (7). 16 of the mutant lines were essentially refractory to $\mathrm{Cbl}$ supplementation after 2-5 d (Table I). Several of these mutant lines were grown in Cbl-supplemented medium for longer periods of time; even after $30 \mathrm{~d}$ in medium containing $1 \mu \mathrm{g} \mathrm{OH}-\mathrm{Cbl} / \mathrm{ml}$, no increase in propionate pathway activity was observed over that activity measured after growth in basal medium. As indicated in Table I, these unresponsive mutants have been designated $m u t^{\circ}$.

On the other hand, seven of the 23 mut mutants examined were deficient in ${ }^{14} \mathrm{C}$ fixation when grown

TABLE I

Utilization of $\left[1-{ }^{14} \mathrm{C}\right]$ Propionate by mut Mutant Human Fibroblasts Cultured in Basal or Cbl-supplemented Medium

\begin{tabular}{|c|c|c|c|c|c|}
\hline \multirow[b]{2}{*}{ Mutant class } & \multirow[b]{2}{*}{ Cell line } & \multicolumn{4}{|c|}{ OH-Cbl concentration $(\mu \mathrm{g} / \mathrm{ml})^{*}$} \\
\hline & & Basal & 0.01 & 0.1 & 1.0 \\
\hline \multirow[t]{16}{*}{$m u t^{\circ}$} & 77 & 0.06 & 0.08 & 0.07 & 0.07 \\
\hline & 184 & 0.09 & 0.09 & 0.09 & 0.08 \\
\hline & 294 & 0.23 & 0.22 & 0.17 & 0.22 \\
\hline & 296 & 0.10 & 0.10 & 0.07 & 0.06 \\
\hline & 354 & 0.15 & 0.16 & 0.15 & 0.09 \\
\hline & 379 & 0.04 & 0.04 & 0.04 & ND $\ddagger$ \\
\hline & 417 & 0.16 & 0.13 & 0.11 & 0.12 \\
\hline & 418 & 0.18 & 0.14 & 0.19 & 0.15 \\
\hline & 437 & 0.25 & 0.28 & 0.26 & 0.24 \\
\hline & 438 & 0.38 & 0.39 & 0.42 & 0.39 \\
\hline & 444 & 0.20 & 0.16 & 0.16 & 0.17 \\
\hline & 454 & 0.11 & 0.13 & 0.16 & 0.13 \\
\hline & 460 & 0.07 & 0.08 & 0.08 & 0.06 \\
\hline & 471 & 0.08 & 0.09 & 0.09 & 0.12 \\
\hline & 507 & 0.04 & 0.03 & 0.03 & 0.04 \\
\hline & 588 & 0.06 & 0.06 & 0.05 & 0.05 \\
\hline \multirow[t]{7}{*}{$m u t^{-}$} & 257 & 0.11 & 0.28 & 1.76 & 2.01 \\
\hline & 378 & 0.14 & 0.17 & 0.21 & 0.27 \\
\hline & 394 & 0.27 & 0.52 & 2.26 & 2.69 \\
\hline & 515 & 0.08 & 0.16 & 0.31 & 0.39 \\
\hline & 550 & 0.23 & 0.34 & 1.85 & 1.97 \\
\hline & 589 & 0.05 & 0.08 & 0.12 & 0.14 \\
\hline & 601 & 0.09 & 0.11 & 0.31 & 0.30 \\
\hline
\end{tabular}

* Cells were grown $2-5 \mathrm{~d}$ in basal medium containing $\sim 30$ $\mathrm{pg} \mathrm{Cbl} / \mathrm{ml}$ or in medium supplemented with the indicated concentration of $\mathrm{OH}-\mathrm{Cbl}$, and assayed for the incorporation of ${ }^{14} \mathrm{C}$ from $\left[1-{ }^{14} \mathrm{C}\right]$ propionate into trichloroacetic acidprecipitable material in $10 \mathrm{~h}$. Data are expressed as nanoatoms ${ }^{14} \mathrm{C}$ per milligram/protein.

† ND, not done. under basal conditions, but displayed significant increases in propionate utilization when grown for 2-5 $\mathrm{d}$ in Cbl-supplemented medium (Table I); these mutants have been designated $m u t^{-}$. In four of the seven responsive $m u t^{-}$mutants, ${ }^{14} \mathrm{C}$ fixation increased one- to threefold after growth in medium containing $1 \mu \mathrm{g} \mathrm{OH}-\mathrm{Cbl} / \mathrm{ml}$; no further increases were observed upon growth for up to $25 \mathrm{~d}$ in Cbl-supplemented medium. In the other three $m^{-} t^{-}$mutants, propionate pathway activity increased 10- to 20-fold maximally (Table I), to values approximately one-half that of controls $(10,13)$.

Mutase activity in mut mutants. The above heterogeneity led us to examine the effect of AdoCbl concentration on the reaction kinetics of mutase in mutant fibroblast extracts. None of the seven $m u t^{\circ}$ mutants examined in this way (lines 77, 184, 418, 438, 454, 471, and 507) had any detectable mutase activity even when assayed in the presence of AdoCbl at concentrations up to $1 \mathrm{mM}$, a value $>10,000$ times the $K_{\mathrm{m}}$ for cofactor of mutase from control cells.

Each of the $m u t^{-}$mutants, on the other hand, did have measurable mutase activity. As shown in Fig. 1, kinetic studies with extracts of six of the mut ${ }^{-}$cell lines revealed markedly elevated $K_{\mathrm{m}}$ for AdoCbl, ranging from 2 to $290 \mu \mathrm{M}$ (control $K_{\mathrm{m}}: 0.04-0.08 \mu \mathrm{M}$ ). Interaction between coenzyme and the mutant apoenzyme in each of these cell lines, as analyzed by double reciprocal plots, appeared to follow simple MichaelisMenten kinetics within the range of AdoCbl concentrations used in each experiment (Fig. 1). Mutase from each of $\mathrm{mut}^{-}$mutants, like control enzyme (12), exhibited a Hill coefficient of 1 toward AdoCbl. ${ }^{2}$ The apparent maximum velocity $\left(\mathrm{V}_{\max }\right)$ of mutase in these $\mathrm{mut}^{-}$ lines were also abnormal, ranging from 7 to $725 \mathrm{pmol} /$ min per mg; by comparison, mutase from control fibroblasts exhibits a $V_{\max }$ under these conditions of 1,053$1,827 \mathrm{pmol} / \mathrm{min}$ per $\mathrm{mg}(7,18)$. Mutase from the seventh mut ${ }^{-}$mutant examined (line 515, Table I) exhibited complex kinetics (Fig. 2A). When the data obtained at AdoCbl concentrations $>7 \mu \mathrm{M}$ were analyzed by a Lineweaver-Burk plot (Fig. 2B), they yielded a straight line with an apparent $K_{\mathrm{m}}$ of $39 \mu \mathrm{M}$. However, at lower AdoCbl concentrations (Fig. 2A) a second component of mutase activity was found, comprising $\sim 15 \%$ of the apparent $\mathrm{V}_{\max }$ and behaving as though it had a $K_{\mathrm{m}}$ of $\sim 2 \mu \mathrm{M}$.

Properties of the mutant enzyme in mut ${ }^{-}$mutants. We studied the effect of DL-methylmalonyl CoA concentration on the reaction kinetics of mutase in crude extracts of $m u t^{-}$lines 257 and 550 . Both mut $^{-}$ mutants examined had a normal $K_{\mathrm{m}}$ for substrate (70 and $100 \mu \mathrm{M}$, respectively; control $K_{\mathrm{m}}=70-140 \mu \mathrm{M}$ ), with a reduced $\mathrm{V}_{\max }$ compared with control (13 and $38 \%$ of the control mean, respectively). Like control 

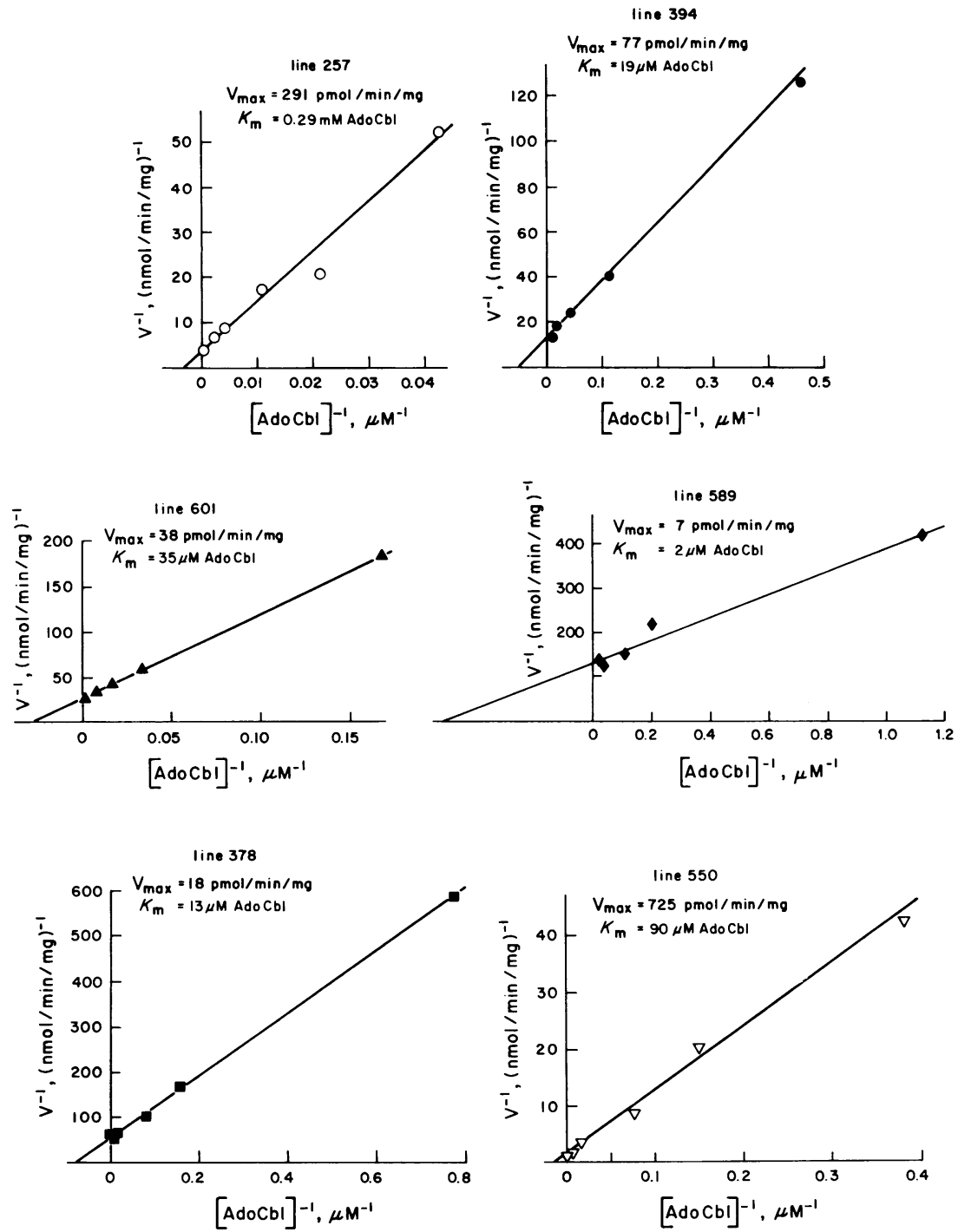

Figure 1 Double reciprocal plots of the effect of AdoCbl concentration on methylmalonyl CoA mutase activity in $\mathrm{mut}^{-}$mutants. Extracts of indicated cell lines grown in basal medium were incubated at $37^{\circ} \mathrm{C}$ with concentrations of AdoCbl between $1.2 \mu \mathrm{M}$ and $1.3 \mathrm{mM}$ for $10 \mathrm{~min}$ before assay. DLmethylmalonyl CoA concentration in these experiments was $0.37-0.42 \mathrm{mM}$. Apparent $\mathrm{V}_{\max }$ and $K_{\mathrm{m}}$ values for AdoCbl were determined from least squares regression analyses of the kinetic data for each cell line and are indicated in the figure.

enzyme (12), mutase from each of these mutant lines exhibited a Hill coefficient of 1 toward substrate. ${ }^{2}$

The thermostability of mutase from $\mathrm{mut}^{-}$mutants 257 and 550 was determined by incubating samples at $45^{\circ} \mathrm{C}$ in $0.2 \mathrm{M}$ Tris/sulfate $(\mathrm{pH} 7.4)$ in the absence or presence of added AdoCbl (Table II, Fig. 3). When incubated at $45^{\circ} \mathrm{C}$ for $15 \mathrm{~min}$ in the presence of excess AdoCbl $(6 \mu \mathrm{M}-0.5 \mathrm{mM})$, extracts of three control lines exhibited as much mutase activity as did these extracts assayed before incubation (Table II). Extracts of mutant lines 500 and 257 , however, incubated at $45^{\circ} \mathrm{C}$ in the presence of $0.5 \mathrm{mM}$ AdoCbl, retained 23 and $<5 \%$, respectively, of the initial mutase activity after $15 \mathrm{~min}$ (Table II). When control and mutant extracts were incubated at $45^{\circ} \mathrm{C}$ for defined intervals without added AdoCbl, mutant apoenzyme from the $2 \mathrm{mut}^{-}$mutants was significantly more labile than apoenzyme from three control lines (Fig. 3, Table II). Comparison of the two experiments shown in Table II indicated that, although AdoCbl completely protected control mutase from thermal inactivation at $45^{\circ} \mathrm{C}$, it was only partially effective in protecting mutant enzyme from line 550 and ineffective in protecting enzyme from line 257.

The apparent turnover rate of normal and mutant 


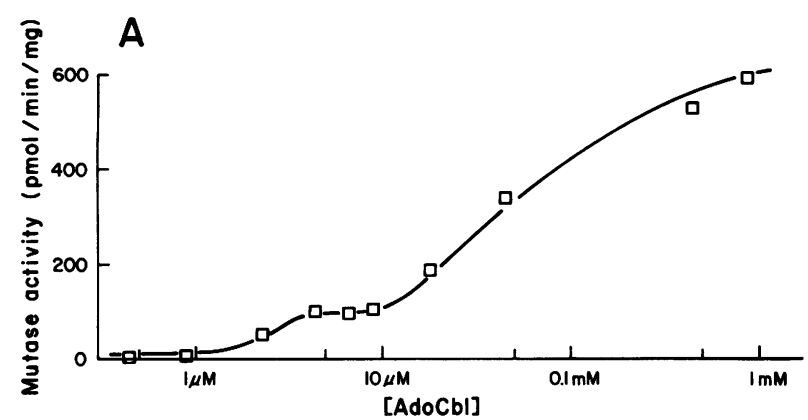

B

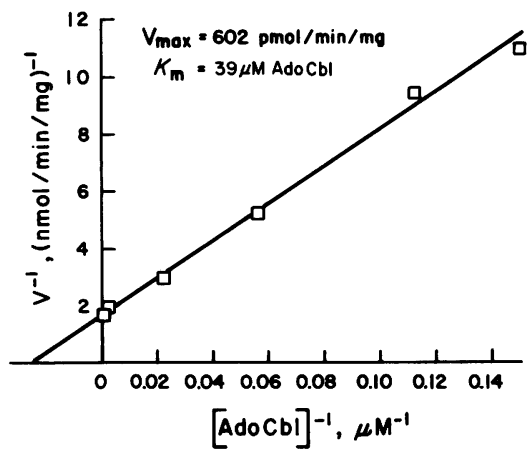

Figure 2 Michaelis-Menten (A) and double reciprocal (B) plots of the effect of AdoCbl concentration on methylmalonyl CoA mutase activity in $m u t^{-}$mutant 515 . After cell growth in basal medium, an extract of line 515 was incubated at $37^{\circ} \mathrm{C}$ with the indicated concentrations of AdoCbl before assay. DL-methylmalonyl CoA concentration was $0.37 \mathrm{mM}$. Complex plot in (A) is consistent with the existence of at least two components of mutase activity. When data at AdoCbl concentrations $>7 \mu \mathrm{M}$ are analyzed by a Lineweaver-Burk plot (B), they yield a straight line. In (B), apparent $\mathrm{V}_{\max }$ and $K_{\mathrm{m}}$ were determined by appropriate least squares regression analyses. See text for discussion.

enzyme was estimated in control cells and in cells from $m u t^{-}$mutant 550 by measuring mutase activity in the presence of added AdoCbl in extracts of cells grown either in the presence or in the absence of the protein synthesis inhibitor cycloheximide (15). Cells from three control lines were grown $4 \mathrm{~d}$ in medium containing $1 \mu \mathrm{g} / \mathrm{ml} \mathrm{OH}-\mathrm{Cbl}$ (during which time mutase apoenzyme molecules are converted to holoenzyme $[10,12])$. Cycloheximide $(15 \mu \mathrm{g} / \mathrm{ml})$ was then added to half of the culture flasks for an additional $24 \mathrm{~h}$. When mutase activity was then measured in cell extracts in the presence of added AdoCbl, cells exposed to cycloheximide exhibited 5-9\% $(n=3)$ less activity than cells grown in Cbl-supplemented medium without cycloheximide. Mutant cells from line 550, on the other hand, cultured in the same way, exhibited 18-20\% ( $n$ $=2$ ) less activity after exposure to cycloheximide than cells not so exposed. These data suggest apparent $t_{1 / 2}$ for normal and mutant mutase of 7-14d and 3-4d, respectively, under these conditions.
Mutase activity in cell lines from mut heterozygotes. We examined eight cell lines derived from parents of mut mutants. After cell growth in basal medium, mutase activity measured in extracts of heterozygous cells without added AdoCbl was within the control range (Table III). When mutase activity was measured with normally saturating amounts of AdoCbl (5.0-8.9 $\mu \mathrm{M})$, however, the mean activity in the eight mut heterozygote lines was significantly $(P<0.001)$ reduced compared with the control mean, although there was extensive overlap between the two ranges (Table III).

After cell growth for $4 \mathrm{~d}$ in medium containing 1 $\mu \mathrm{g} \mathrm{OH}-\mathrm{Cbl} / \mathrm{ml}$, the endogenous holomutase activity in each cell line from a mut heterozygote increased markedly (Table III). When compared with mutase activities in control cells grown in Cbl-supplemented medium, however, mutase activity in extracts of these lines was approximately half of normal $(P<0.001)$. Moreover, under Cbl-supplemented growth conditions, the control and heterozygote ranges did not overlap (Table III).

Codominant expression of mut alleles. We examined the possibility that at least part of the mutase activity from some or all of the heterozygote cell lines might display abnormal kinetics with respect to cofactor. Extracts of each of these cell lines were prepared, and mutase activity was assayed in the presence of both

TABLE II

Thermostability of Methylmalonyl CoA Mutase Activity from Control and mut ${ }^{-}$Mutant Cells

\begin{tabular}{|c|c|c|c|c|}
\hline \multirow{2}{*}{\multicolumn{2}{|c|}{ Incubation at $45^{\circ} \mathrm{C}$}} & \multicolumn{3}{|c|}{$\begin{array}{l}\text { Residual mutase activity } \\
\text { (percent of initial activity) }\end{array}$} \\
\hline & & & $\boldsymbol{m u t}^{-}$ & \\
\hline \multirow[t]{2}{*}{ Conditions } & Time & Control & mutant 550 & mutant 257 \\
\hline & $\min$ & & & \\
\hline With added & 0 & $(100)$ & $(100)$ & $(100)$ \\
\hline AdoCbl* & 15 & $93-117 \ddagger$ & 23 & $<5$ \\
\hline Without added & 0 & $(100)$ & $(100)$ & $(100)$ \\
\hline AdoCbl§ & 15 & $10-20 \ddagger$ & $<5$ & $<5$ \\
\hline
\end{tabular}

* Extracts of cells grown in basal medium were incubated in the presence of $6 \mu \mathrm{M}$ AdoCbl (control) or $0.45 \mathrm{mM}$ AdoCbl (mutants) at $45^{\circ} \mathrm{C}$ for $15 \mathrm{~min}$. Mutase activity was then measured at $37^{\circ} \mathrm{C}$; data represent residual activity expressed as a percentage of the initial activity without incubation at $45^{\circ} \mathrm{C}$.

$\$$ Data reflect range of values obtained with three control lines.

$\S$ Extract of cells grown in basal medium were incubated in the absence of added AdoCbl at $45^{\circ} \mathrm{C}$ for the indicated period of time. Mutase activity was then assayed at $37^{\circ} \mathrm{C}$ in the presence of $6 \mu \mathrm{M}$ AdoCbl (control) or $0.45 \mathrm{mM}$ AdoCbl (mutants). Data represent residual activity expressed as a percentage of the initial activity without incubation at $45^{\circ} \mathrm{C}$. 


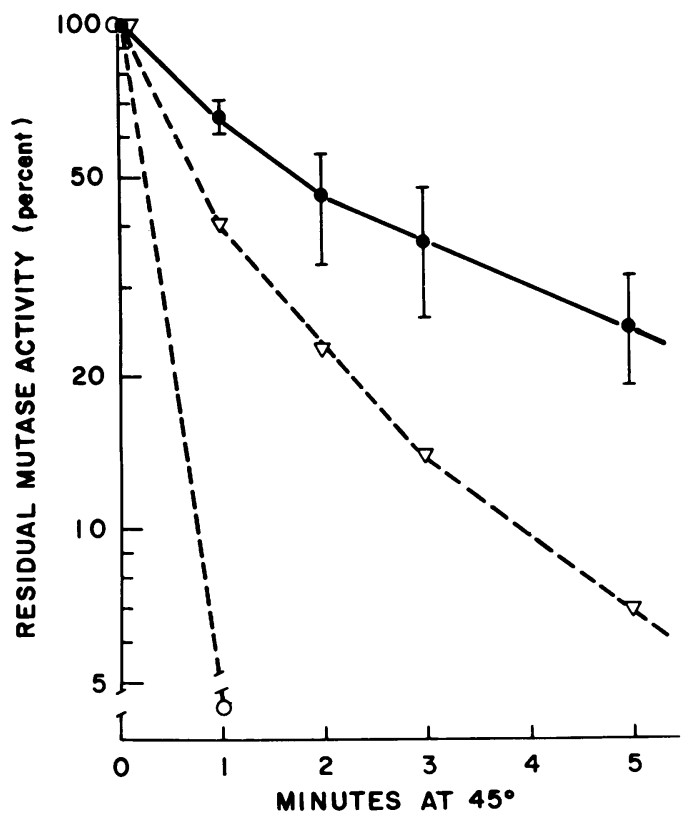

Figure 3 Thermal stability of methylmalonyl CoA mutase activity from control and mutant cells. Extracts of three control lines $(\odot)$ and $m u t^{-}$mutants $550(\nabla)$ and $257(\bigcirc)$ were incubated at $45^{\circ} \mathrm{C}$ for 1-5 min in the absence of added AdoCbl after cell growth in basal medium. Mutase activity was then measured at $37^{\circ} \mathrm{C}$ in the presence of $6 \mu \mathrm{M}$ (controls) or 0.45 $\mathrm{mM}$ AdoCbl (mutants). Data represent residual activity expressed as a percentage of the initial activity without incubation at $45^{\circ} \mathrm{C}$. Control data reflect mean and range of values obtained with three control lines. Data shown for mutant line 550 are from a representative experiment. For mutant line 257 , no residual activity ( $<5 \%$ of initial activity) was detected after $1-5 \mathrm{~min}$ at $45^{\circ} \mathrm{C}$. See Table II.

$6 \mu \mathrm{M}$ AdoCbl, and $1 \mathrm{mM}$ AdoCbl. Lines 187, 188, and 509 , derived from parents of $m u t^{\circ}$ mutants, did not exhibit any detectable increase in activity at $1 \mathrm{mM}$
AdoCbl over that activity measured at $6 \mu \mathrm{M}$ AdoCbl; these cell lines, therefore, behaved similarly to several control lines (e.g., Fig. 4A). On the other hand, mutase activity in extracts of the other five mut heterozygote cell lines (four lines from parents of $\mathrm{mut}^{-}$mutants, one line from a parent of a $m u t^{\circ}$ mutant) was $9-42 \%$ higher when measured at $1 \mathrm{mM}$ AdoCbl than when measured at $6 \mu \mathrm{M}$ AdoCbl, indicating a component of total mutase activity that could only be detected in the presence of high AdoCbl concentrations.

The above data suggest that five of the eight mut heterozygotes examined express some mutase activity with reduced affinity for cofactor. To examine this phenomenon further, we repeated the above experiment over a wider range of cofactor concentrations. As seen in Fig. 4A, mutase from mut ${ }^{-}$heterozygote 613 exhibited complex enzyme kinetics, consistent with the existence of at least two classes of enzyme molecules with either high or low affinity for AdoCbl. As determined by linear regression analyses, these two components exhibited apparent $K_{\mathrm{m}}$ of $0.037 \mu \mathrm{M}$ and 54 $\mu \mathrm{M}$, similar to the $K_{\mathrm{m}}$ exhibited by control enzyme and by the mutant enzyme of the propositus in this family, mut ${ }^{-}$mutant 550, respectively. Almost identical findings were obtained for cell line 612 , derived from the other parent of mutant $550 .^{2}$ Similar experiments were performed with cell lines 508 and 509, derived from the parents of $m u t^{\circ}$ mutant 507. Although line 507 had undetectable mutase activity even at AdoCbl concentrations up to $0.45 \mathrm{mM}$ (Fig. 4B), mutase from line 508 exhibited complex kinetics, similar to those of line 613. Cells from line 509, on the other hand, exhibited no component of mutase activity with a $K_{\mathrm{m}}$ for AdoCbl different from control (Fig. 4B).

We also investigated the thermostability of mutase activity at $45^{\circ} \mathrm{C}$ in four of the mut heterozygote cell

TABLE III

Methylmalonyl CoA Mutase Activity in Cultured Human Fibroblasts from Controls and mut Heterozygotes after Cell Growth in Basal or Cbl-supplemented Medium

\begin{tabular}{|c|c|c|c|c|}
\hline \multirow[b]{3}{*}{ Class } & \multicolumn{4}{|c|}{ Mutase activity } \\
\hline & \multicolumn{2}{|c|}{ Basal medium* } & \multicolumn{2}{|c|}{ Supplemented medium ${ }^{*}$} \\
\hline & $\begin{array}{l}\text { No AdoCbl } \\
\text { added }\end{array}$ & $\begin{array}{l}\text { With added } t \\
\text { AdoCbl }\end{array}$ & $\begin{array}{l}\text { No AdoCbl } \\
\text { added }\end{array}$ & $\begin{array}{l}\text { With added } \ddagger \\
\text { AdoCbl }\end{array}$ \\
\hline & \multicolumn{4}{|c|}{$\mathrm{pmol} / \mathrm{min} / \mathrm{mg}$} \\
\hline Control & $\begin{array}{l}58 \pm 10[4] \S \\
18-139(34)^{\sharp}\end{array}$ & $\begin{array}{l}1,709 \pm 80[4] \S \\
898-2,646(51)^{\|}\end{array}$ & $\begin{array}{l}982 \pm 65[4] \S \\
780-1,260(20)^{\|}\end{array}$ & $\begin{array}{l}2,091 \pm 135[4] \S \\
1,512-2,715(26)^{\prime \prime}\end{array}$ \\
\hline mut heterozygotes & $\begin{array}{l}64 \pm 18[5] \S \\
19-101(9)^{\prime \prime}\end{array}$ & $\begin{array}{l}798 \pm 54[8] \S \\
325-1,562(22)^{\prime \prime}\end{array}$ & $\begin{array}{l}406 \pm 55[8] \S \\
172-572(12)^{\prime \prime}\end{array}$ & $\begin{array}{l}784 \pm 96[8] \S \\
352-1,144(13)^{\prime \prime}\end{array}$ \\
\hline
\end{tabular}

\footnotetext{
* Cells were grown for $4 \mathrm{~d}$ in either basal medium or in medium containing $1 \mu \mathrm{g} \mathrm{OH}-\mathrm{Cbl} / \mathrm{ml}$.

$\$$ Mutase activity was measured in the presence of 5.0-8.9 $\mu \mathrm{M}$ AdoCbl.

$\S$ Mean \pm SEM. Numbers in brackets indicate the number of cell lines examined.

"Range of values obtained. Numbers in parentheses indicate the total number of observations made, each in duplicate.
} 

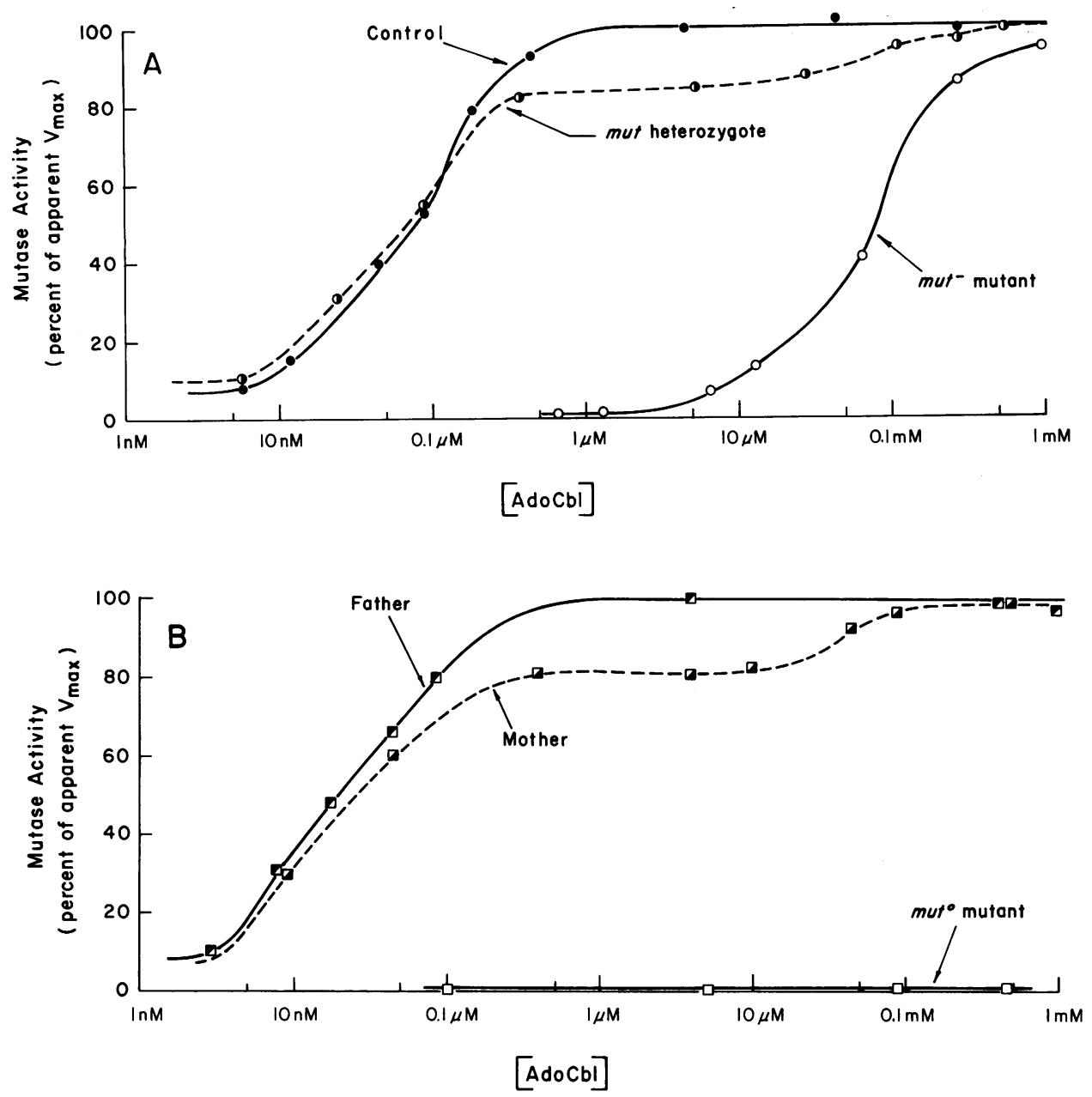

FIGURE 4 Michaelis-Menten plots of effect of AdoCbl concentration on methylmalonyl CoA mutase activity in extracts of cell lines from controls, mut mutants, and mut heterozygotes. (A) After cell growth in basal medium, extracts of control line $87(\bullet), m^{-} t^{-}$mutant $550(0)$, and mut heterozygote 613 (from the father of $m u t^{-}$mutant $550[0]$ ) were incubated at $37^{\circ} \mathrm{C}$ with the indicated concentrations of AdoCbl for $10 \mathrm{~min}$ before assay. DL-methylmalonyl CoA concentration in each experiment was $0.37 \mathrm{mM}$. The respective $V_{\max }$ of these three cell lines were 1,770 , 510 , and $1,271 \mathrm{pmol} / \mathrm{min}$ per $\mathrm{mg}$ protein. (B) After cell growth in basal medium, extracts of $m u t^{\circ}$ mutant $507(\square)$ and of cell lines from that patient's mother and father, lines 508 ( $\square$ ) and 509 $(\square)$, respectively, were incubated at $37^{\circ} \mathrm{C}$ with varying concentrations of $\mathrm{AdoCbl}$, as above. The respective $V_{\max }$ of these three cell lines were $<2,492$, and $836 \mathrm{pmol} / \mathrm{min}$ per $\mathrm{mg}$ protein.

lines. When extracts of control lines were incubated at $45^{\circ} \mathrm{C}$ for $15 \mathrm{~min}$ in the presence of $6 \mu \mathrm{M}$ AdoCbl, essentially all of the initial mutase activity was recovered (93-117\%; see Table II). Under the same conditions, extracts of lines 187 and 188 (parents of $m u t^{\circ}$ mutant 184) retained 97 and $98 \%$ of the initial mutase activity, respectively, whether incubated at 6 $\mu \mathrm{M}$ or $0.45 \mathrm{mM}$ AdoCbl. Extracts of lines 612 and 613 (parents of mut $^{-}$mutant 550), on the other hand, retained only $84 \%$ and $75 \%$ of initial mutase activity, respectively, when both incubated and assayed with $0.45 \mathrm{mM}$ AdoCbl. Similarly, when an extract of cell line 613 was incubated for $15 \mathrm{~min}$ at $45^{\circ} \mathrm{C}$ in the presence of $6 \mu \mathrm{M}$ AdoCbl and then assayed at the same concentration, mutase activity was $76 \%$ of that measured without prior incubation at $45^{\circ} \mathrm{C}$.

\section{DISCUSSION}

The experiments presented in this report represent attempts to gain insight into the nature of the inherited defect in a series of cell lines from mut homozygotes and mut heterozygotes with defects involving the methylmalonyl CoA mutase apoenzyme. Several observations indicate that the mutase deficiency in each of the mutant cell lines studied is the result of a 
primary defect in the apoenzyme. First, these cell lines accumulated $\mathrm{Cbl}$ normally and synthesized significant amounts of the two $\mathrm{Cbl}$ coenzymes, in agreement with data on other presumptive apomutase mutants $(3,4,7)$. Second, complementation analysis indicated that each of the mutant cell lines could be uniquely assigned to a single complementation group that is genetically distinct from the four known defects in $\mathrm{Cbl}$ metabolism. And third, these mut cell lines were severely deficient in mutase activity measured in crude fibroblast extracts at normally saturating AdoCbl concentrations.

A number of the cell lines, designated $m u t^{\circ}$, had no defectable activity ( $<0.1 \%$ of the control mean) at AdoCbl concentrations up to $1 \mathrm{mM}$. Seven other cell lines, designated $\mathrm{mut}^{-}$, expressed measurable, although still deficient, levels of activity at very high AdoCbl concentrations. The mutant enzyme from each of the seven $\mathrm{mut}^{-}$mutants examined demonstrated a markedly elevated $K_{m}$ for AdoCbl (Figs. 1 and 2). In a series of genetic complementation tests, there was no indication of even partial complementation of the mutase deficiency in heterokaryons formed between any of the $m u t^{\circ}$ and any of the $m u t^{-}$mutants. Thus, although there is considerable biochemical heterogeneity within the mut complementation group (Table $\mathrm{I}$ ), there is as yet no reason to suspect that the $m u t^{\circ}$ and $m u t^{-}$mutations involve different gene loci. This conclusion is also supported by the recent finding of Fenton and Rosenberg that human mutase is a dimer of identical subunits. $^{3}$ This genetic and biochemical evidence, together with the demonstration that some cell lines belonging to the mut $^{-}$class have a mutase enzyme with biochemically defined abnormalities in a number of physical and kinetic parameters, indicates that the $m u t^{-}$defects-and, by extension, the entire mut complementation group - result from allelic mutations at the structural gene locus for the mutase apoenzyme.

On the nature of the defect in mut ${ }^{-}$mutants. At least two types of information indicate that mut ${ }^{-}$ mutants are characterized by a structurally abnormal mutase apoenzyme. ${ }^{4}$ First, the data in Figs. 1 and 2 suggest that the mutant enzyme in cell extracts from fibroblast cultures grown in basal medium retain maximally $\sim 1-50 \%$ of control activity and have $K_{\mathrm{m}}$ for AdoCbl $\sim 50$ - to 5,000-fold greater than normal. And

\footnotetext{
${ }^{3}$ Fenton, W. A., and L. E. Rosenberg. Unpublished experiments.

${ }^{4}$ One mut $^{-}$mutant cell line (line 589) was derived from a patient described by Kang et al. (19), who suggested that this cell line was specifically deficient in the activity of methylmalonyl CoA racemase. Our findings do not support this claim; line 589 appears to express a mut $^{-}$defect of the mutase apoenzyme. Unpublished experiments (Willard, H. F., A. Gertler, W. A. Fenton, and L. E. Rosenberg) have also provided evidence that line 589 has normal racemase activity, comparable to that detected in other mut mutants.
}

second, in at least two mut ${ }^{-}$mutants, the mutant apoenzyme appears to be significantly more thermolabile than control enzyme (Table II, Fig. 3). Affinity of mutant enzyme for methylmalonyl CoA appears to be normal in the mut $^{-}$mutants examined thus far (lines 257 and 550 [this paper] and line 515 [9]), indicating that the various mutations that result in altered interaction with AdoCbl may not substantially affect the integrity of the substrate binding site.

On the nature of the defect in mut ${ }^{\circ}$ mutants. The precise nature of the inherited lesion in $m u t^{\circ}$ mutants is obscure at present. These cell lines have no demonstrable mutase activity in crude fibroblast extracts at any feasible concentration of added AdoCbl, are severely deficient in propionate utilization despite normal AdoCbl synthesis, and are completely refractory to $\mathrm{Cbl}$ supplementation in culture. There are at present no data available to suggest whether a mutant protein exists at all in such cell lines, although some $m u t^{\circ}$ mutants have clearly detectable levels of ${ }^{14} \mathrm{C}$ fixation (e.g., lines 294, 437, and 438 in Table I), which might reflect exceedingly low levels of intracellular holoenzyme.

Codominant expression of mut alleles and evidence for genetic compounds. The data presented here provide considerable evidence that normal alleles and mutant mut alleles are codominantly expressed. First, extracts of fibroblasts from obligate heterozygotes for a $m u t$ defect exhibit mutase activity reduced to $\sim 50 \%$ or less of the control mean activity under appropriate conditions (Table III). The detection of reduced activity in heterozygotes of both sexes indicates that the mut mutation is inherited in an autosomal fashion. A similar reduction in activity of mutase in extracts of leukocytes from mut heterozygotes has been reported by Narisawa et al. (20). Second, a number of these mut heterozygote cell lines contain mutase which exhibits complex enzyme kinetics consistent with the expression of both a mutant and a normal allele (Fig. 4A, B). And third, mutase in some of the mut heterozygotes is more thermolabile than control enzyme, again implying the existence of mutase molecules with both normal and mutant properties.

Not unexpectedly, all four cell lines derived from parents of $m u t^{-}$mutants exhibited evidence of a mutant allele with an abnormal $K_{m}$ for AdoCbl (e.g., Fig. 4A). Surprisingly, however, one of the four cell lines derived from parents of $m u t^{\circ}$ mutants also expressed a mutant allele with an apparently reduced affinity for cofactor (Fig. 4B). This unexpected pedigree-a $m u t \%$ $m u t^{+}$father (line 509) and a $m u t^{-} / m u t^{+}$mother (line 508) having a phenotypically $m u t^{\circ}$ child (line 507) suggests that the patient from whom line 507 was derived is actually a $m u t^{\circ} / m u t^{-}$genetic compound. At least two explanations could account for the complete deficiency of mutase activity (hence a $m u t^{\circ}$ 
phenotype) in line 507. First, the $m u t^{-}$allele inherited from the mother could be extremely labile, such that it could only be stabilized by the presence of a normal allele $\left(m u t^{+}\right)$directing the synthesis of normal mutase subunits. Because no normal allele exists in line 507, the $\mathrm{mut}^{-}$allele would not be detected. Second, the absence of activity might result if the heteropolymer formed between these particular $m u t^{\circ}$ and $m u t^{-}$ alleles was inactive.

Another example of a possible genetic compound is $m u t^{-}$mutant 515. At AdoCbl concentrations $>7 \mu \mathrm{M}$, this mutant exhibits a $K_{\mathrm{m}}$ for AdoCbl of $39 \mu \mathrm{M}$ (Fig. 2B), in good agreement with the $K_{\mathrm{m}}$ originally reported for this cell line by Morrow et al. (9). However, a kinetic analysis of mutase activity in this cell line at lower AdoCbl concentrations provided evidence for an additional component, with a $K_{\mathrm{m}}$ on the order of $2 \mu \mathrm{M}$ (Fig. 2A). The examination of cell lines from the parents of this $m u t^{-}$mutant might be particularly informative in elucidating the precise basis for these complex kinetics; in the meantime, the data are most consistent with the expression of two distinct $m u t^{-}$alleles in cell line 515, one with $\sim 1,000$-fold elevated $K_{\mathrm{m}}$ for AdoCbl and one with $\sim 50$-fold elevated $K_{\mathrm{m}}$. Thus, at least two of the mut mutants examined appear to have inherited demonstrably different mutant alleles from each of their two parents.

\section{ACKNOWLEDGMENTS}

The authors wish to thank Wayne Fenton, Marilyn Feldman, Rosalie Blunden, and Jane Goldberg for their assistance. We are also indebted to our many colleagues who sent us the cell lines used in this study.

This work was supported in part by a research grant from the National Institutes of Health (A.M 12579).

\section{REFERENCES}

1. Fenton, W. A., and L. E. Rosenberg. 1978. Genetic and biochemical analysis of human cobalamin mutants in cell culture. Annu. Rev. Genet. 12: 223-248.

2. Mahoney, M. J., A. C. Hart, V. D. Steen, and L. E. Rosenberg. 1975. Methylmalonicacidemia: biochemical heterogeneity in defects of $5^{\prime}$-deoxyadenosylcobalamin synthesis. Proc. Natl. Acad. Sci. U. S. A. 72: 2799-2803.

3. Morrow, G., M. J. Mahoney, C. Mathews, and J. Lebowitz. 1975. Studies of methylmalonyl coenzyme A carbonylmutase activity in methylmalonic acidemia. I. Correlation of clinical, hepatic, and fibroblast data. Pediatr. Res. 9: 641-644.

4. Linnell, J. C., D. M. Matthews, S. H. Mudd, B. W. Uhlendorf, and I. J. Wise. 1976. Cobalamins in fibroblasts cultured from normal control subjects and patients with methylmalonic acidemia. Pediatr. Res. 10: 179-183.

5. Gravel, R. A., M. J. Mahoney, F. H. Ruddle, and L. E. Rosenberg. 1975. Genetic complementation in het- erokaryons of human fibroblasts defective in cobalamin metabolism. Proc. Natl. Acad.Sci. U.S. A. 72: 3181-3185.

6. Willard, H. F., I. S. Mellman, and L. E. Rosenberg. 1978. Genetic complementation among inherited deficiencies of methylmalonyl CoA mutase activity: evidence for a new class of human cobalamin mutant. Am. J. Hum. Genet. 30: 1-13.

7. Willard, H. F., and L. E. Rosenberg. 1977. Inherited deficiencies of human methylmalonyl CoA mutase activity: reduced affinity of mutant apoenzyme for adenosylcobalamin. Biochem. Biophys. Res. Commun. 78: 927-934.

8. Rosenberg, L. E., and C. R. Scriver. 1980. Disorders of amino acid metabolism. In Metabolic Control and Disease. P. K. Bondy, and L. E. Rosenberg, editors. W. B. Saunders Company, Philadelphia. 583-776.

9. Morrow, G., R. Clark, J. Lebowitz, and D. T. Whelan. 1978. A new variant of methylmalonic acidemia-defective coenzyme-apoenzyme binding in cultured fibroblasts. Clin. Chim. Acta. 85: 67-72.

10. Willard, H. F., and L. E. Rosenberg. 1979. Inborn errors of cobalamin metabolism: effect of cobalamin supplementation in culture on methylmalonyl CoA mutase activity in normal and mutant human fibroblasts. Biochem. Genet. 17: 57-75.

11. Böhlen, P., S. Stein, W. Dairman, and S. Udenfriend. 1973. Fluorometric assay of proteins in the nonogram range. Arch. Biochem. Biophys. 155: 213-220.

12. Willard, H. F., and L. E. Rosenberg. Interactions of methylmalonyl CoA mutase from normal human fibroblasts with adenosylcobalamin and methylmalonyl CoA: evidence for non-equivalent active sites. Arch. Biochem. Biophys. In press.

13. Willard, H. F., L. M. Ambani, A. C. Hart, M. J. Mahoney, and L. E. Rosenberg. 1976. Rapid prenatal and postnatal detection of inborn errors of propionate, methylmalonate, and cobalamin metabolism: a sensitive assay using cultured cells. Hum. Genet. 34: 277-283.

14. Fenton, W. A., and L. E. Rosenberg. 1978. Improved techniques for the extraction and chromatography of cobalamins. Anal. Biochem. 90: 119-125.

15. Youngdahl-Turner, P., I. S. Mellman, R. H. Allen, and L. E. Rosenberg. 1979. Protein-mediated vitamin uptake: adsorptive endocytosis of the transcobalamin II-cobalamin complex by cultured human fibroblasts. Exp. Cell Res. 118: $127-134$.

16. Morrow, G., and J. Lebowitz. 1976. Studies of methylmalonyl CoA carbonylmutase activity in methylmalonic acidemia. II. In vitro binding kinetics with adenosylcobalamin. Biochem. Med. 15: 241-245.

17. Morrow, G., L. A. Barness, G. J. Cardinale, R. H. Abeles, and J. G. Flaks. 1969. Congenital methylmalonic acidemia: enzymatic evidence for two forms of the disease. Proc. Natl. Acad. Sci. U. S. A. 63: 191-197.

18. Willard, H. F. 1979. Ph.D. thesis, Yale University. 281 pp.

19. Kang, E. S., P. J. Snodgrass, and P. S. Gerald. 1972. Methylmalonyl coenzyme A racemase defect: another cause of methylmalonic aciduria. Pediatr. Res. 6: 875-879.

20. Narisawa, K., T. Saito, S. Hisa, H. Susuki, K. Hayasaka, T. Arakawa, K. Konno, S. Tsuchida, and Y. Tsuchiya. 1977. Methylmalonyl CoA mutase activity of leukocytes in variants and heterozygotes of methylmalonic acidemia. Tohoku J. Exp. Med. 123: 1-8. 